\title{
Eclectic Paradigm and the analysis of FDI in tourism in Nepal
}

\author{
Sandeep Basnyat*
}

\begin{abstract}
TThis paper analyzes the factors that determine the inflows of FDI in tourism sector of Nepal using Eclectic Theory (Paradigm) propounded by John Dunning. It was observed that the first and second conditions (ownership specific advantages and internalization advantages) are firm specific determinants of FDI, whereas, the third is location-specific and, therefore, has a crucial influence on the host country Nepal's inflows of FDI in tourism. It was further observed that the development impact of FDI on the tourism industry of Nepal may be determined by various combinations of three main important factors--policy environment, including policy reforms that trigger further inflows of FDI; the level of development (and maturity) of the tourism industry; and, the geography of Nepal. The paper suggests that MNCs can help Nepal by, among other things, diversifying the supply of tourism products and improving the local service standards.
\end{abstract}

Keywords: FDI, eclectic paradigm, OLI theory, tourism investment.

\section{Introduction}

The five year plans of Nepal have conventionally placed tourism below manufacturing and/or agriculture, as it was not considered as an important source of economic growth. However, these days, a "quiet but significant reappraisal" is taking place even in Nepal, which values tourism as a potential means of earning export revenues, generating large numbers of jobs - including for young people and women - promoting economic diversification and a more services-oriented economy, helping to revive declining urban areas and cultural activities, and opening up remote rural areas (UNCTAD, 1999a). In this context, like many other developing countries, Nepal is looking to tourism as a potentially promising avenue for economic development by attracting foreign investment through multinational enterprises (MNEs).

MNE is a recent phenomenon, with the vast majority developing only in the post-World War II years. However, the motivations for international expansion and the nature of MNEs' offshore activities have evolved significantly over this relatively short period (Birkinshaw, 2003). It is interesting to observe how the United Nations has changed its

\footnotetext{
* Sandeep Basnyat is a facutly of economics at Ace Institute of Management, a tourism researcher and a freelance economist.
} 
definition of the MNE as these companies have grown in size and importance. In 1973, it defined such an enterprise as one "which controls assets, factories, mines, sales offices, and the like in two or more countries." By 1984, it had changed the definition to an enterprise (a) comprising entities in two or more countries, regardless of the legal form and fields of activity of those entities; (b) which operates under a system of decision making permitting coherent policies and a common strategy through one or more decisionmaking centers; and (c) in which the entities are so linked, by ownership or otherwise, that one or more of them may be able to exercise a significant influence over the activities of the others, in particular to share knowledge, resources, and responsibilities (Birkinshaw, 2003). In essence, the changing definition highlights the importance of both strategic and organizational integration, and thereby, the active, coordinated management of operations located in different countries, as the key differentiating characteristic of an MNE (Birkinshaw, 2003). In context of Nepal, such resources committed can take the form of skilled people or research equipment just as easily as plants and machinery or computer hardware.

In context of tourism, data provided by Department of Industry of the government of Nepal shows that there has not been significant FDI inflows; however, and looking at the trend, it surely explains that the amount of FDI in tourism is promising in the future. This study is largely based on the analysis of the facts MNEs take into consideration while making their investment decision in Nepal in general, and in particularly, in tourism sector.

\section{Eclectic Paradigm and FDI}

Eclecticism is a conceptual approach that does not hold rigidly to a single paradigm or set of assumptions, but instead draws upon multiple theories, styles, or ideas to gain complementary insights into a subject, or applies different theories in particular cases. It can sometimes seem inelegant or lacking in simplicity, and eclectics are sometimes criticized for lack of consistency in their thinking. It is, however, common in many fields of study. For example, most psychologists accept certain aspects of behaviorism, but do not attempt to use the theory to explain all aspects of human behavior (Gray, 2003).

Eclecticism was first recorded to have been practiced by a group of ancient Greek and Roman philosophers who attached themselves to no real system, but selected from existing philosophical beliefs those doctrines that seemed most reasonable to them. Out of this collected material they constructed their new system of philosophy. The term comes from the Greek meaning "choosing the best" (Gray, 2003).

Definitions of FDI are contained in the Balance of Payments Manual: Fifth Edition (BPM5) (Washington, D.C., International Monetary Fund, 1993) and the Detailed Benchmark Definition of Foreign Direct Investment: Third Edition (BD3) (Paris, Organisation for Economic Co-operation and Development, 1996). According to the BPM5, FDI refers to an investment made to acquire lasting interest in enterprises operating outside of the economy of the investor. Further, in cases of FDI, the investor's purpose is to gain an effective voice in the management of the enterprise. The foreign entity or group of associated entities that makes the investment is termed the "direct investor". The unincorporated or incorporated enterprise-a branch or subsidiary, respectively, in 
which direct investment is made-is referred to as a "direct investment enterprise". Some degree of equity ownership is almost always considered to be associated with an effective voice in the management of an enterprise; the BPM5 suggests a threshold of 10 per cent of equity ownership to qualify an investor as a foreign direct investor (IMF, 1993).

Once a direct investment enterprise has been identified, it is necessary to define which capital flows between the enterprise and entities in other economies should be classified as FDI. Since the main feature of FDI is taken to be the lasting interest of a direct investor in an enterprise, only capital that is provided by the direct investor either directly or through other enterprises related to the investor should be classified as FDI. The forms of investment by the direct investor which are classified as FDI are equity capital, the reinvestment of earnings and the provision of long-term and short-term intra-company loans (between parent and affiliate enterprises) (IMF, 1993).

According to the BD3 of the OECD, a direct investment enterprise is an incorporated or unincorporated enterprise in which a single foreign investor either owns 10 per cent or more of the ordinary shares or voting power of an enterprise (unless it can be proven that the 10 per cent ownership does not allow the investor an effective voice in the management) or owns less than 10 per cent of the ordinary shares or voting power of an enterprise, yet still maintains an effective voice in management (OECD, 1996). An effective voice in management only implies that direct investors are able to influence the management of an enterprise and does not imply that they have absolute control. The most important characteristic of FDI, which distinguishes it from foreign portfolio investment, is that it is undertaken with the intention of exercising control over an enterprise (OECD, 1996).

The Eclectic theory related to foreign investment, stated as Eclectic Paradigm, was evolved by John Dunning, emeritus professor at the Rutgers University (United States) and University of Reading (United Kingdom) and was studied combining three different determinants together (Gray, 2003). These three different determinants are collectively known as OLI paradigm is a mix of 3 various theories and has been used in this study to analyze tourism investments in Nepal with the conceptual framework that the level and structure of a firm's foreign investment will depend on ownership specific advantages $(\mathrm{O})$, location specific advantages (L) and internalization (I). Dunning (1993) suggests that:

"[..] a firm's value adding activities will depend on three conditions being satisfied:

(1) The extent to which it possesses sustainable ownership specific advantages vis-à-vis firm's of other nationalities in particular markets it serves or is contemplating serving.

(2) $[\ldots]$ the extent to which the enterprises perceives it to be in its best interest to add value to its $(\mathrm{O})$ advantages rather than to sell them, or their right of use, to foreign firms. These advantages are called market internalization advantages.

(3) Assuming conditions (1) and (2) are satisfied, the extent to which the global interests of the enterprise are served by creating, or utilizing it $(\mathrm{O})$ advantages in a foreign location (L). (Dunning 1993, p.79). 
The $(\mathrm{O})$ advantages largely take the form of the privileged possession of intangible assets as well as those which arise as a result of the common governance of cross border value added activities. These advantages and the use made of them are assumed to increase the wealth creating capacity of a firm and hence the value of its assets. Having satisfied with the $(\mathrm{O})$ advantages, (I) may reflect either the greater organizational efficiency of hierarchies or their ability to exercise monopoly power over the assets under their governance. Finally, the distribution of these resources and capabilities is assumed to be uneven and, hence depending on their distribution, will confer an (L) advantage on the countries possessing them over those who do not (Dunning 1993, p.79).

It was observed that the first and second conditions are firm specific determinants of FDI, whereas, the third is location-specific and, therefore, has a crucial influence on the host country Nepal's inflows of FDI. If only the first condition is met, firms will rely on exports, licensing or the sale of patents to service a foreign market. However, if the second condition is added to the first, FDI becomes the preferred mode of entry, but only in the presence of location specific advantages. Hence, analysis of all three factors, within the trinity of conditions for FDI to occur, location specific determinants are the only ones that Nepal as a host country can influence directly.

\section{Methodology}

Qualitative approach has been applied to analyze the data, which have been compiled from both primary and secondary sources, comparative analysis and descriptive interpretation method is used to explain the trends and phenomena. The Eclectic Paradigm (OLI Theory) has been cited from John Dunning's Multinational Enterprises and The Global Economy (1993), while report on The Determinants of Foreign Direct Investment by UNCTAD (1998) has also been taken as a reference while analyzing OLI paradigm. As stated earlier, the paper analyses investment in tourism sector of Nepal as a dependent variable and L - advantage as independent variables and examined how different sets of determinants relating to $\mathrm{L}$ variables have contributed to the growth of tourism investment in Nepal.

As a major secondary sources of data, World Investment Reports published by UNCTAD from 1996 to 2013 have been chosen. Similarly various other books, journal articles, reports published by government and non-governmental organizations and scholars and also internet have been utilized to collect information and data for the use of secondary purpose of analyzing motives, trends and policy reforms. For the primary source of data, a sample survey was done among the various tourism affiliates invested or owned fully or partly by the foreigners in Nepal. The collected information were verified and used further to compare and support secondary data.

\section{Theoretical Framework and Analysis of Eclectic Paradigm}

This paper has assigned investment in tourism sector of Nepal as a dependent variable and all of the above three advantages $(\mathrm{O}, \mathrm{L}$ and $\mathrm{I})$ in general and L-advantage in particular as independent variables and examined how different sets of determinants relating to Ladvantage variables have contributed to the growth of tourism investment in Nepal. From 
theoretical as well as empirical analysis it was obtained that the decisions of multinational companies may be affected by their own desire to hold control over the foreign affiliates; however, the ability of a particular country, such as Nepal, to attract foreign direct investment (FDI) in tourism is heavily dependent upon its location specific advantages (L) including the availability of natural and other resources, input prices and costs, investment environment, availability of transportation and communication facilities, economic growth rate and government strategies and polices.

\section{O - Ownership Advantages (or FSA - Firm Specific Advantages)}

This firm specific advantage is usually intangible and can be transferred within the multinational enterprise at low cost (e.g., technology, brand name, benefits of economies of scale). The advantage either gives rise to higher revenues and/or lower costs that can offset the costs of operating at a distance in an abroad location.

A Multinational enterprise operating a plant in a foreign country is faced with additional costs paralleled to a local competitor (Gray, 2003). These additional costs could be specified as:

- failure of knowledge about local market conditions

- legal, institutional, cultural and language diversities

- the increased costs of communicating and operating at a distance

Consequently, if a foreign firm is to be successful in another country, it must have some kind of an advantage that vanquishes the costs of operating in an abroad market. Either the firm must be able to earn higher revenues, for the same costs, or have lower costs, for the same revenues, than comparable native firms. Since merely abroad firms have to pay "costs of foreignness", they must have other methods to earn either higher revenues or have lower costs in order to able to stay in business (Gray, 2003). The Multinational enterprise must have some separate advantages with its competitors, if it want to be profitable abroad. Advantages must be particular to the firm and readily transferable between countries and within the firm. These advantages are called ownership or core competencies or firm specific advantages (FSAs) (Gray, 2003).

Gray (2003) mentions that the firm has a monopoly over its firm specific advantages and can utilize them abroad, resulting in a higher marginal return or lower marginal cost than its competitors, and thus in more profit. Existing three basic types of ownership advantages (or Firm Specific Advantages) for a multinational enterprise, that it can posses are:

- monopolistic advantages that receive to the Multinational enterprise in the form of privileged access to output and input markets through ownership of scarce natural resources, patent rights, and the like.

- technology, knowledge broadly defined so as to contain all forms of innovation activities

- economies of large size (advantages of common governance) such as economies 
of learning, economies of scale and scope, broader access to financial capital throughout the Multinational enterprise organization, and advantages from international diversification of assets and risks.

\section{Location Advantages (or Country Specific Advantages - CSA)}

The firm must use some foreign factors in connection with its native Firm Specific Advantages (FASs) in order to earn full rents on these FSAs. Therefore the locational advantages of different countries are key in determining which will become host countries for the Multinational enterprises (Gray, 2003). Clearly the relative attractiveness of various locations can change over time so that a host country can to some extent engineer its competitive advantage as a location for foreign direct investment.

The country specific advantages (CSAs) can be separate into three classes:

- E - Economic advantages consists of the quantities and qualities of the factors of production, transport and telecommunications costs, scope and size of the market, and etc.

- P - Political Advantages include the common and specific government policies that influence inward Foreign Direct Investment flows, intra-firm trade and international production.

- S - Social, cultural advantages include psychic distance between the home and host country, language an cultural diversities, general attitude towards foreigners and the overall position towards free enterprise.

\section{I - Internalization Advantages (IA).}

Gray (2003) also mentions that the Multinational enterprises has several choices of entry mode, ranking from the market (arm's length transactions) to the hierarchy (wholly owned subsidiary). The Multinational enterprises chooses internalization where the market does not exist or functions poorly so that transactions expenses of the external route are high.

The subsistence of a particular know-how or core ability is an asset that can give rise to economic rents for the firm. These rents can be earned by licensing the Firm Specific Advantages to another firm, exporting products using this Firm Specific Advantages as an input, or adjustment subsidiaries abroad.

Although the three strands - O, L and I advantages - in the explanation of FDI interact with each other, conceptually it can be argued that they should be considered separately (Dunning, 1993). This can be understood with the fact that the ownership specific advantages such as trademark, production technique, entrepreneurial skills, returns to scale refer to the competitive advantages of the enterprises seeking to engage foreign direct investment (FDI). The greater the competitive advantages of the investing firms, the more they are likely to engage in their foreign production. Whereas, location specific advantages such as existence of raw materials, low wages, special taxes or tariffs are the 
attractions that provide an alternative for the foreign investors for undertaking the value adding activities of MNCs in sectors such as tourism. The more the immobile, natural or created resources, which firms need to use jointly with their own competitive advantages, favor a presence in a foreign location, the more firms will choose to augment or exploit their O specific advantages by engaging in FDI (Dunning, 1993).

In contrast to the above two, the internalization advantages are the advantages by own production rather than producing through a partnership arrangement such as licensing or a joint venture. Firms may organize the creation and exploitation of their core competencies. The greater the net benefits of internalizing cross-border intermediate product markets, the more likely a firm will prefer to engage in foreign production itself rather than license the right to do so (Dunning, 1993).

Some companies internationalize by gradually moving up the scale, from exporting through joint venturing to direct foreign investment. Others prefer to move straight to the high-commitment-high-control mode of operating, in part because they are entering mature markets in which it would be very difficult to build a business from nothing. Still others choose to adopt a low-commitment-low-control mode, such as exporting or subcontracting. It is also important to emphasize that some firms are "born global," establishing significant international operations at or near their founding (UN, 2008). Whether this is due to their internal orientation, or the need to move quickly due to the nature of their product or services, such firms do not take such an incremental approach. This is exactly what is seen in tourism sector of Nepal with the emergence of Hyatt Regency Hotel, Pizza Hut and KFC in Kathamandu.

\begin{tabular}{|c|l|c|c|c|}
\hline \multicolumn{2}{|c|}{} & \multicolumn{3}{|c|}{ Category of Advantages } \\
\cline { 2 - 5 } & $\begin{array}{c}\text { Ownership } \\
\text { advantages }\end{array}$ & $\begin{array}{c}\text { Internalization } \\
\text { Advantages }\end{array}$ & $\begin{array}{c}\text { Location Specific } \\
\text { Advantages }\end{array}$ \\
\hline \multirow{2}{*}{$\begin{array}{c}\text { Forms of } \\
\text { Market Entry }\end{array}$} & Licensing & Yes & No & No \\
\cline { 2 - 5 } & Export & Yes & No & Yes \\
\cline { 2 - 5 } & FDI & Yes & Yes & Yes \\
\hline
\end{tabular}

Source: Dunning (1981)

In dependence of the categories of advantage there can be chosen the form of the international activity. If a company has ownership advantages like having knowledge about the target market abroad, for example hotel staff with language skills, information about import permissions of certain food not usually available in local markets, appropriate products, contacts and so on, it can do a licensing as in the case of Pizza Hut in Nepal. The licensing is less cost-intensive than the other forms of internalization.

If there are internalization advantages, the company can invest more capital abroad. This can be achieved by export in form of an export subsidiary. The FDI is the most capital intensive activity that a company can choose. According to Dunning, it is considered 
that locational advantages are necessary for FDI. This can be realized by hotels which are either bought or completely constructed abroad (Dunning, 1981).

\section{Eclectic Paradigm and FDI in Tourism in Nepal}

As mentioned earlier in the paper, ownership advantages incorporates monopolistic advantages that is received by the multinational enterprise in the form of privileged access to output and input markets through ownership of scarce natural resources, patent rights, and the like. Similarly, additional advantages relate to technology, knowledge broadly defined so as to contain all forms of innovation activities. Similarly, foreign firms should have economies of large size (advantages of common governance) such as economies of learning, economies of scale and scope, broader access to financial capital throughout the multinational enterprise organization, and advantages from international diversification of assets and risks.

Nepal still remains as agrarian economy with agriculture as its principal economic activity, employing $80 \%$ of the population and providing $37 \%$ of GDP (MOI, 2012). Only about $20 \%$ of the total area is cultivable; another $33 \%$ is forested; most of the rest is mountainous. In addition, economic development in social services and infrastructure has not made dramatic progress due to GDP dependency on India. There are, however, a number of small foreign investments coming to Nepal via the Non Resident Nepali, who are investing in Shopping Mall, Plaza, Real Estate Business, Tourism etc. None of these investments are of the large scale due to lack of market size and scope (MOI, 2012).

Nepal's capital market is still underdeveloped (NRB, 2012). The trading of listed securities at the stock exchanges, often known as secondary capital market transactions, is new for Nepal. Although Biratnagar Jute Mill and Nepal Bank Limited floated their shares in the market in 1937, the formal trading of secondary market in Nepal was started only in 1994 after the establishment of Nepal Stock Exchange. Initially, there were only 62 companies with 25 brokers. The trading system was open outcry system. The most significant change in Nepali secondary market was the establishment of semi-automated system in August 24, 2007 (NRB, 2012).

Currently, NEPSE has increased the number of brokerage houses and more number of companies are listed. It is extremely imperative that Nepal is to address structural changes required to shield the banking sector and the economy from internal and external shocks. It includes consolidating the financial institutions, ensuring sound corporate governance, strengthening internal project and loan analysis, more effective monitoring and control, and better understanding and monitoring of the activities of cooperatives (NRB, 2012). These evidences highlight the fact that ownership advantages are not the primary factors that determine the investment decision of MNEs in Nepal (NRB, 2012).

Despite the fact that the multinational enterprises has several choices of entry mode, ranking from the market (arm's length transactions) to the hierarchy (wholly owned subsidiary), the multinational enterprises chooses internalization on those markets where the market does not exist or functions poorly so that transactions expenses of the external route are high. In such markets, the subsistence of a particular know-how or core ability 
is an asset that can give rise to economic rents for the firm. These rents can be earned by licensing the Firm Specific Advantages to another firm, exporting products using this Firm Specific Advantages as an input, or adjustment subsidiaries abroad (Dunning, 1993).

It seems logical to draw inferences of the fact that internalization advantages may have contributed to some of the MNEs to implement their investment decisions in tourism sector of Nepal. However, the core circumstances provide different explanations, more particularly the deterioration of country's economy due to political instability.

The political instability has affected Nepal's economy and people's faith in the country's future. Since the end of the 10-year Maoist insurgency in 2006, the inclusion of the former rebels in the government in 2007 and the abolishment of the monarchy in 2008 - Nepal has been hit with one political crisis after another. The country has been without a parliament for more than a year, after major political parties missed yet another deadline to write a constitution and reach a consensus on the structure of the government. The economic outlook for Nepal hinges on how political uncertainties are resolved as the investor confidence is depressed by concerns over the political transition. Several reports have stressed on promotion and an enabling of business environment and political stability to improve economic performance in Nepal. In such situations, foreign investor's confidence in licensing the Firm Specific Advantages to another firm in Nepal, exporting products using this Firm Specific Advantages as an input, or adjustment subsidiaries abroad are far-away dreams.

Nepal has been receiving some foreign direct investment (FDI), but the amount has been insignificant when compared with that received by other developing countries, including South Asian one. But the list of foreign investors includes such renowned companies as British American Tobacco (BAT), Unilever, Coca- Cola, Standard Chartered and Hyatt. India is the major source of FDI in Nepal so far (about 40\%), followed by the United States, China, The British Virgin Islands, Norway, Japan, the Republic of Korea, Canada and Hong Kong (China) in terms of the amount of approved FDI (MOI, 2012).

The major area of FDI has been manufacturing, followed by services and, in particular, tourism more specifically, FDI is concentrated in manufacturing products for export to India (e.g. vegetable fat, soap, tooth paste, Ayurvedic preparations) and overseas (readymade garments). This is followed by hotels. Recent FDI in Nepal is attributed to taking advantage of the further policy liberalization in services sector (MOI, 2012).

The latest value for Foreign direct investment, net (BoP, current US\$) in Nepal was $\$ 87,799,640.00$ as of 2010 . Over the past 14 years, the value for this indicator has fluctuated between $\$ 87,799,640.00$ in 2010 and $(\$ 6,647,984.00)$ in 2006. Similarly, the latest value for Foreign direct investment, net inflows (BoP, current US\$) in Nepal was $\$ 87,816,140.00$ as of 2010 . Over the past 38 years, the value for this indicator has fluctuated between $\$ 87,816,140.00$ in 2010 and $(\$ 6,647,984.00)$ in 2006. More recent report from UNCTAD shows that FDI inflows to Nepal in 2011 was \$95 million, an uptick from $\$ 87$ million in 2010 (MOI, 2012). 
Number of Registered Industries in Tourism Sector up to F.Y. 2011 / 2012 in Nepal

\begin{tabular}{|l|r|}
\hline Number of Large scale industries registered & 72 \\
\hline Number of Medium scale industries registered & 145 \\
\hline Number of small scale industries registered & 638 \\
\hline Number of Total industries registered & 855 \\
\hline
\end{tabular}

Source: Ministry of Industry, Nepal. 2011/12

Note: Foreign investment companies are only small scale industries.

Approved Projects for Foreign Investment and Technology

Transfer by Type \& Scale in Tourism Up to F.Y 2011/12

\begin{tabular}{|c|c|c|c|c|c|c|}
\hline \multirow{2}{*}{$\begin{array}{c}\text { No. of } \\
\text { Industries }\end{array}$} & \multicolumn{3}{|c|}{ Type } & \multicolumn{3}{c|}{ Scale } \\
\cline { 2 - 7 } & $\begin{array}{c}\text { Equity } \\
\text { Investment }\end{array}$ & $\begin{array}{c}\text { Equity Investment } \\
\text { and Tech. Transfer }\end{array}$ & $\begin{array}{c}\text { Technology } \\
\text { Transfer }\end{array}$ & Small & Medium & Large \\
\hline 625 & 613 & 6 & 6 & 552 & 34 & 39 \\
\hline
\end{tabular}

Source: Ministry of Industry, Nepal. 2011/12

Above data provided by the Ministry of Industry,Government of Nepal shows that the hotel and tourism industry attracted a large number of investments given the attractiveness of Nepal as a tourist destination. Although tourism has experienced a major setback in recent years because of the civil war, this is certainly an area where Nepal has an intrinsic comparative advantage in terms of location specific advantages.

\section{Location specific advantages of Nepal for FDI in tourism}

After ten years of insurgency, now that there is peace and security and the biggest hindrance for attracting foreign investments has been removed. What are the other conditions that must be fulfilled to attract FDI? There are many conditions that have to be put in place to attract FDI. It is important to ensure an attractive investment climate. Consistent macroeconomic policies, good governance, economic stability, guarantee of property rights, rule of law and absence of corruption are among the conditions required to attract FDI. Consistency and predictability in economic policies and political stability are preconditions to attract FDI (Rana and Pradhan, 2005).

As stated earlier, many countries have taken policy measures to promote their tourism sector with the intention of attracting more investment so as to maximize its potential as a growth sector. It is estimated that in some developing countries, tourism is already worth more than traditional commodity based or manufacturing exports in terms of export 
revenues and share in GDP. Furthermore, since tourism has started to attract more FDI, the sector has become an important avenue for reducing the resource gap in developing countries like Nepal by contributing to gross capital formation, and skills and technology transfer, and by creating jobs, thereby reducing poverty (Rana and Pradhan, 2005).

Tourism is also one of the sectors with potential for "shared growth", given its ability to employ unskilled labour and establish linkages with many other sectors of the economy. Thus the development dimension of FDI in the tourism industry is considered to be much broader than that of other competing sectors for FDI such as mining. On the other hand, the long and cross-cutting nature of the tourism value chain means that any negative effects of tourism FDI will also be very widespread (Athukorala and Sharma, 2006).

It is clear that the development impact of FDI on the tourism industry of Nepal may be determined by various combinations of three main (among other important) factors (Athukorala and Sharma, 2006).First, and more importantly, is the policy environment, including policy reforms that trigger further inflows of FDI (both generally, and in the tourism industry). This can be broadened to include the perception that the foreign and domestic private sectors will effectively benefit from each other, which can help to create a welcoming environment (Athukorala and Sharma, 2006).

The second set of factors that determine the impact of tourism-related FDI is the level of development (and maturity) of the tourism industry in a Nepal. In economies like Nepal where tourism is a mature sector the tourism industry has built confidence in local sourcing, resulting perhaps in stronger and wider linkages with the domestic economy. Many country studies have suggested that the more mature the industry, the higher is the level of confidence in domestic private suppliers and their capacity to meet the industry's demands. Consequently there will be greater linkages of TFDI with the local economy, resulting in a positive impact (Athukorala and Sharma, 2006).

Third, geography of Nepal also plays an important role in influencing the nature of impact in two ways (Athukorala and Sharma, 2006). One is in terms of natural resource endowment, where Nepal can be distinguished by the extent to which it can offer beach versus wildlife (safari) or other natural tourist attractions. It is important to note that the impact of the latter type of tourism product (wildlife/natural resource attraction) appeared to involve a greater engagement with local communities in terms of sourcing and corporate social responsibility. This has usually been associated with foreign more than domestic investments. Furthermore, it is in this type of tourism that most impacts appeared to be felt in the immediate vicinity, compared to for example beach or business (urban) tourism, where impacts are spread more widely (Athukorala and Sharma, 2006).

Nepal has been receiving about 60 per cent of FDI from China and India while the remainder has originated from Organization for Economic Cooperation and Development (OECD) countries. The country has also been pursuing various policies to attract FDI. Entering the World Trade Organization (WTO) in 2004, participating as a representative in the Bay of Bengal Initiative for Multi-Sectoral Technical and Economic Cooperation (BIMSTEC), and becoming a member of South Asian Free Trade Area (SAFTA) in 2004 are some of the endeavors (MOI, 2012). More recently, a new Trade Policy (2010), a new Industrial Policy (2010) and Nepal Trade Integration Strategy (2010) have also been 
released. At high level, the country convened Bilateral Investment Promotion and Protection Agreement (BIPPA) with India in 2011. With the United States, Nepal signed a Trade and Investment Framework Agreement (TIFA) in 2010. She has also signed investment protection covenants with France and Germany. Further, in order to eschew double taxation, agreements have been concluded with India, Norway and Thailand (MOI, 2012).

The law of Nepal also assures the security of investments against nationalization. Besides this, Nepal being a member of Multilateral Investment Guarantee Agency (MIGA) assures the foreign investors against non-commercial risks like currency transfer, breach of contract, war and civil disturbances in the country. As of July 2004, according to the statistics of foreign investment division of Department of Industry, there are about 905 foreign direct investment projects in Nepal that worth approximately US\$ 1.65 billion. These projects in the sectors like Agriculture/Forestry; Manufacturing; Energy; Construction; Mineral; Tourism and other Service related industries have generated employment opportunities to almost 95,000 people in Nepal. India, USA, China, UK, Norway, Japan, South Korea and Germany are the leading countries with highest number of projects in Nepal (MOI, 2012).

Despite having huge potential and supporting policy and legal environment for attracting FDI in Nepal, we have not been able see a considerable surge in its inflows. There are several technical and non-technical reasons behind this. Persistent labor problems, power outages, political instability, cumbersome regulations and tax regime (leading to high transaction costs), corruption, and lack of adequate infrastructure (leading to high transportation costs), among others factors, are impacting FDI inflows to Nepal (Ghimire, 2001). According to Enterprise Survey 2009, 62 percent of enterprises think instability is the biggest constraint despit having plenty of opportunities for FDI in agriculture and agro-based industries, flowers and flowering plants, Pashmina, garments, tourism, health, education, IT, nursing homes, construction, hydropower and alternative energy sources, and manufacturing, among other sectors (Ghimire, 2001).

\section{Conclusion}

Tourism is a fast-growing industry that involves many economic and social sectors, making it an excellent development vector. Not surprisingly, the above surveys have also shown that tourism is a high-priority industry for investment in Nepal. With growing international competition between tourism destinations and higher contestability of investment projects, effective promotion is crucial in order to attract investors in the sector.

Tourist destinations like Nepal do not only aim to attract financial capital from abroad, but also human capital, such as entrepreneurs, hospitality and travel managers, and international franchises to market and develop local attractions. In fact, such activities are often pursued very successfully, whereas the attraction of foreign capital for tourism projects often presents more of a challenge. Shortage of capital is a major obstacle for tourism development, and many countries - especially in the developing world such as Nepal - increasingly look to foreign investors to provide capital that will help development of their tourism industries. Multinational corporations (TNCs) in the tourism sector, 
therefore, have often had a positive impact on host destinations. Apart from investing capital, foreign MNCs can help Nepal by, among other things, diversifying the supply of tourism products and improving the local service standard. However, attracting FDI in the tourism sector is often difficult, and there is a growing demand for support in this area from the government.

\section{References}

Athukorala, P.C., \& Sharma, K. (2006). Foreign Investment in a Least Developed Country: The Nepalese Experience. Transnational Corporations, 15, (2), 125 - 146.

Birkinshaw, J (2003). Transnational Management: Text, Cases and Readings in CrossBorder Management. Singapore: McGraw Hill Companies.

Dunning, J., \& M. McQueen (1981). The eclectic theory of production: a case study of the international hotel industry. Managerial and Decision Economics, (21), 197-210.

Dunning, J. H. (1993). Multinational Enterprises and the World Economy. Wokingham: Addison-Wesley.

Dunning J. H. (1989). Transnational Corporations and the Growth of Services: Some Conceptual and Theoretical Issues. UNCTC Current Studies Series, A. No. 9., Sales no. E.89.II.A.5. New York: United Nations publication.

Ghimire, K. B. (ed.) (2001). The native tourist: Mass tourism within developing countries. United Kingdom: Earthscan Publications Ltd.

Gray, H. P. (ed.) (2003). Extending the Eclectic Paradigm in the International Business. Great Britain: Edward Elgar Publishing, Inc.

International Monetary Fund (1993). Balance of Payments Manual: Fifth Edition (BPM5). Washington, D.C.: International Monetary Fund.

Ministry of Industry (2012). Statistical Surveys 2012. Kathmandu: Ministry of Industry, Government of Nepal.

Nepal Rastra Bank (2012). Annual Report 2012. Kathmandu: Nepal Rastra Bank.

Organization for Economic Co-operation and Development (1996). Detailed Benchmark Definition of Foreign Direct Investment: Third Edition (BD3). Paris: Organization for Economic Co-operation and Development.

Oppermann, M. (1993). Tourism space in developing countries. Annals of Tourism Research, 22 (1), 151-171.

OMT/UNCTAD (2001). Tourism in the Least Developed Countries. Madrid: OMT.

Rana, M. SJB., \& Pradhan, S. M. (2005). Evaluation of Foreign Direct Investment Policy in Nepal. Economic Policy Network, Policy Paper-1. Kathmandu: Confederation of Nepalese Industries.

UNCTAD (2008) . FDI and Tourism: The Development Dimensions. East and Southern Africa. New York: United Nations Press. 
82 Journal of Tourism and Hospitality (Vol. 5)

UNCTAD (2007a). FDI in Tourism: The Development Dimension. United Nations publication. Sales no. E.07.II.D.17. New York and Geneva: United Nations Press.

UNCTAD (2007b). World Investment Prospects Survey 2007-2009. United Nations publication. New York and Geneva: United Nations Press.

UNCTAD (1999a). Foreign Direct Investment and the challenge of development. World Investment Report. New York and Geneva: United Nations Press

UNESCAP (2001). Promotion of Investment in Tourism Infrastructure. United Nations publication. ST/ESCAP/2133. New York : United Nations Press.

UNWTO (2008). Tourism Highlights - 2008 Edition. Madrid: UNWTO.

UNWTO (2004b). Sustainable development of tourism - conceptual definition. Retrieved September 15, 2013 from http://www.unwto.org/sdt/mission/en/mission. 